\title{
Evaluation of soil salinity level through NDVI in Syrdarya province, Uzbekistan
}

\author{
Abdulla Djuraev ${ }^{1, *}$, Dilmurod Mirdjalalov ${ }^{2}$, Alisher Nuratdinov ${ }^{3}$, Tuychi Khushvaktov ${ }^{4}$, and \\ Yunus Karimov ${ }^{5}$ \\ ${ }^{1}$ Tashkent Institute of Irrigation and Agricultural Mechanization Engineers, Kari Niyazi str., 39, \\ 100000, Tashkent, Uzbekistan \\ ${ }^{2}$ Tashkent Institute of Architecture and Construction, Navoi str., 13, Tashkent, Uzbekistan \\ ${ }^{3}$ Karakalpak State University named after Berdaq, CH. Abirov str., 1, Nukus, Karakalpakstan, \\ Uzbekistan \\ ${ }^{4}$ Tashkent State Agrarian University, University str., 2, 100140 Tashkent province, Uzbekistan \\ ${ }^{5}$ Xinjiang Institute of Ecology and Geography, Chinese Academy of Sciences, South Beijing Road, \\ 818, Urumqi, Xinjiang, China
}

\begin{abstract}
Traditional soil salinity assessments have been doing by collecting of soil samples and laboratory analyzing of collected samples for determining TDS and electro conductivity, but, GIS and Remote Sensing technologies provides more efficient, economic and rapid tools and techniques for soil salinity assessment and soil salinity mapping. Main goals of this research are to map soil salinity of Syrdarya province, to show relation of its result with soil quality index (arable land validity point) values of this field. The soil quality index data and map of 2019 year were digitized and transferred to ArcMap software format and investigated the soil quality index score. As a source of satellite images has been used Landsat OLI 8 Earth-observation satellite. Syrdarya province, every arable land validity point of different locations were measured by State Commite of the Republic of Uzbekistan of Land Resources, Geodesy, Cartography and State Cadastre was compared to our research conducted on satellite sensor and it can be said that the study have done correctly.
\end{abstract}

\section{Introduction}

In particular, one of the urgent tasks today is to ensure effective use of existing irrigated lands, preserve, restore and improve soil fertility and ensure their targeted use [1-3]. Decree of the First President of the Republic of Uzbekistan on April 13, 2013 No. PD-1958 "On measures to further improve the ameliorative status of irrigated lands and rational use of water resources for 2013-2017" and the implementation of this resolution on February 24, 2019 Cabinet of Ministers No. 39 concerning "On the territory Republic" of the State Committee for Land Resources, Geodesy of Irrigated Agricultural Land, a study is being conducted on soil maps [4-8]. Traditional soil salinity assessments have been doing by collecting of soil samples and laboratory analyzing of collected samples for determining

\footnotetext{
*Corresponding author: a.juraev@tiiame.uz
} 
TDS and electro conductivity [5, 14]. However, traditional methods of soil salinity assessment are slow and expensive, because sampling requires long time activities $[3,6,9]$. The time consummation of traditional methods has been stated by Ghabour and Daels [10], but GIS and Remote Sensing technologies provides more efficient, economic and rapid tools and techniques for soil salinity assessment and soil salinity mapping $[4,11,12]$. As well as, in Uzbekistan the research institutes and projects, which are responsible for soil salinity assessment using GIS tools in high level. Current, two main organizations are doing soil salinity assessment in study area $[1,5,8]$. They are "Tuproq bonitirovakasi" LLC and Hydrologic meliorative expedition of Syrdarya province. Both organizations are using GIS tools only for mapping and visualization of data. The methodology for soil salinity assessment has been developed by State Scientific Research Institute of Soil Science and Agro chemistry. SSRISSAC is main research institute for soil surveys in the Republic [5].

Nowadays, the institute is developing advanced methods for soil salinity assessment, which includes GIS and RS technologies. Thus, the main goal of this research is to map soil salinity of Syrdarya province, to show relation of its result with soil quality index (arable land validity point) values of this field.

\section{Materials and methods}

\subsection{Study area}

The study area is located in Syrdarya province of Uzbekistan. Syrdarya province falls in the latitudes $40^{\circ} 58^{\prime} 06^{\prime \prime}$ to $41^{\circ} 05^{\prime} 47^{\prime \prime} \mathrm{N}$ and longitudes $67^{\circ} 52^{\prime} 36^{\prime \prime}$ to $68^{\circ} 04^{\prime} 44^{\prime \prime}$ E. (Fig. 1). The area of the province is 4,300 square kilometers [11]. According to Hydrologic ameliorative expedition of Syrdarya province, $2,764.79 \mathrm{~km}^{2}$ agricultural lands are affected by different salinity degrees [5].

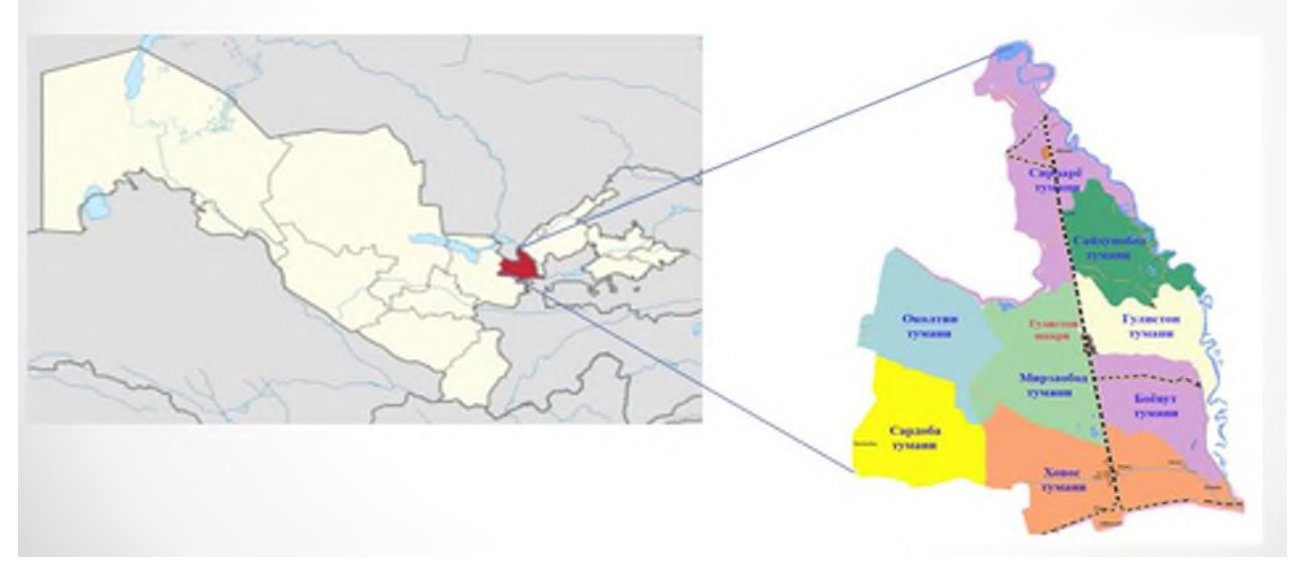

Fig. 1. Map of the study area.

\subsection{Materials}

Soil quality indexation is a comparative estimate of the level of soil quality and natural productivity at the average level of agricultural cultivation. Soil bartering plays an important role in elaboration of normative assessment of the lands of agricultural commodity producers, allocation of land for farmers, establishment of single land tax, prevention of unauthorized allocation of cultivated land for non-agricultural purposes, land 
use and organization of rational use of land. Soil quality index points (Table 1), based on the requirements of cotton sampling, also reflect the quality of irrigated soils cultivated by all other crops in the cotton-growing complex [13].

Table 1. Quality of arable land in Syrdarya province in 2019.

\begin{tabular}{|c|c|c|c|c|c|c|c|c|c|c|c|c|c|}
\hline & \multirow{5}{*}{ 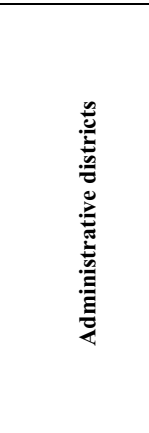 } & \multicolumn{10}{|c|}{ Groups of cadaster } & \multirow{5}{*}{ 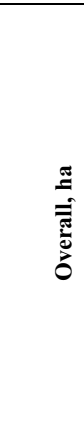 } & \multirow{5}{*}{ 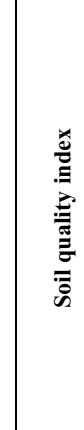 } \\
\hline \multirow[t]{4}{*}{ \# } & & \multicolumn{2}{|c|}{ 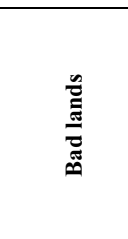 } & \multicolumn{2}{|c|}{ 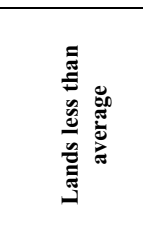 } & \multicolumn{2}{|c|}{ 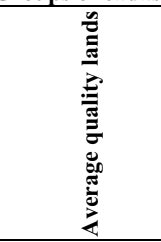 } & \multicolumn{2}{|r|}{ 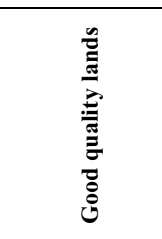 } & \multicolumn{2}{|c|}{ 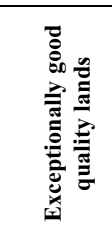 } & & \\
\hline & & \multicolumn{10}{|c|}{ Forms of cadaster } & & \\
\hline & & \multicolumn{9}{|c|}{ Soil quality index values } & 10 & & \\
\hline & & $\begin{array}{l}0- \\
10\end{array}$ & $\begin{array}{l}11- \\
20\end{array}$ & $\begin{array}{c}21- \\
30\end{array}$ & $31-40$ & $41-50$ & $51-60$ & $61-70$ & $71-80$ & $\begin{array}{l}81- \\
90\end{array}$ & $\begin{array}{c}91- \\
10 \\
0\end{array}$ & & \\
\hline \multicolumn{14}{|c|}{ In'000 hectares } \\
\hline 1 & Al-altin & - & - & - & 1.1 & 13.7 & 11.7 & 16.3 & 0.06 & - & - & 42.9 & 56 \\
\hline 2 & Sardoba & - & - & - & 6.7 & 16.2 & 6.8 & 6.1 & - & - & - & 35.9 & 49 \\
\hline 3 & Khavos & - & - & 0.1 & 6.7 & 24.5 & 4.3 & 2.8 & - & - & - & 38.3 & 47 \\
\hline 4 & Mirzaabad & - & - & 0.3 & 9.9 & 18.1 & 5.9 & 1.3 & - & - & - & 35.6 & 45 \\
\hline 5 & Sirdarya & - & - & - & 0.1 & 3.8 & 11.2 & 9.2 & 52.1 & - & - & 29.5 & 61 \\
\hline 6 & Gulistan & - & - & - & 0.5 & 7.8 & 9.0 & 5.1 & 0.5 & - & - & 22.9 & 54 \\
\hline 7 & Saykhunabad & - & - & - & 0.1 & 8.2 & 11.1 & 9.7 & - & - & - & 29.2 & 56 \\
\hline 8 & Boyout & - & - & 0.1 & 1.5 & 12.9 & 9.7 & 8.1 & 0.8 & - & - & 33.1 & 54.5 \\
\hline & Overall, ha & - & - & 0.5 & 26.7 & 105 & 69.8 & 58.6 & 6.5 & - & - & 267 & 52.5 \\
\hline
\end{tabular}

The soil quality index data and map of 2019 year (paper maps from "Tuproq bonitirovkasi" LLC) were digitized and transferred to ArcMap software format and investigated the soil quality index score (Fig. 2).

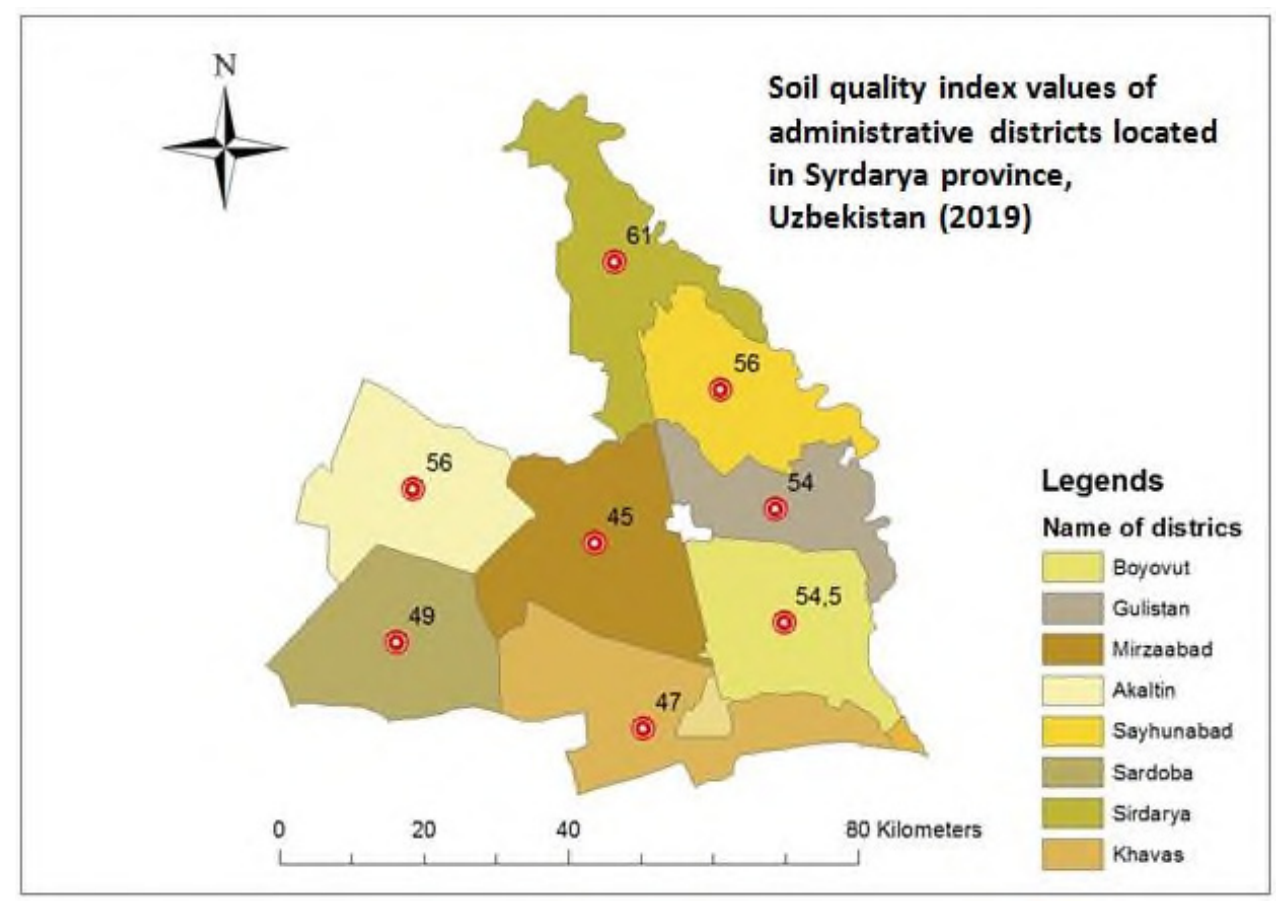

Fig. 2. Soil quality index values of the study area. 
The satellite images of Syrdarya province (Path 154, Row 32) for 2019 years have been downloaded from open sources (earthexplorer.usgs.gov). As a source of satellite images has been used Landsat OLI 8 Earth-observation satellite, which launched on October 16, 2019 (salinity level of arable land peaks after vegetation period in the second half of October and the beginning of November). Once every 16 days the satellite is capturing image by high spectral sensors the entire worldview. The spatial resolution of images is 30 meters, which means one pixel of the image is $30 \times 30$ meter of ground view [15].

\subsection{Methodology}

First of all, remotely sensed Landsat OLI 8 image was projected to the WGS 1984 UTM Zone $42 \mathrm{~N}$ coordinate system and clipped to the extent of the study area. After that, we used an NDVI mask to extract the saline areas. The Normalized Difference Vegetation Index (NDVI) raster layers were calculated using the following Equation 1 [12]:

$$
N D V I=(\text { Band } 5-\text { Band } 4) /(\text { Band } 5+\text { Band } 4)^{*}
$$

* This formula can be used only for Landsat OLI 8 satellite sensor.

The range of NDVI values was divided into 5 classes (Table 2), linked to the soil salinity classification (no salinization, weak, moderate, severe, and very severe salinization) (Table 2).

Table 2. Hypothetical NDVI range for soil salinity levels.

\begin{tabular}{|c|c|}
\hline NDVI range & Soil salinity level \\
\hline $0.15-0.25$ & Very severe salinization \\
\hline $0.26-0.40$ & Severe salinization \\
\hline $0.41-0.55$ & Moderate salinization \\
\hline $0.56-0.70$ & Weak salinization \\
\hline $0.71-1.00$ & Non-salinization \\
\hline
\end{tabular}

In this case, atmospheric and radiometric correction are not in demand, because, Landsat OLI 8 sensor does these corrections itself during capturing remotely images.

\section{Results and discussion}

We have analysed and implemented vegetation index to achieve our goal and as a consequence, it can be detected that arable land without salt content is partially not exist in soil salinity map (Fig. 3). 


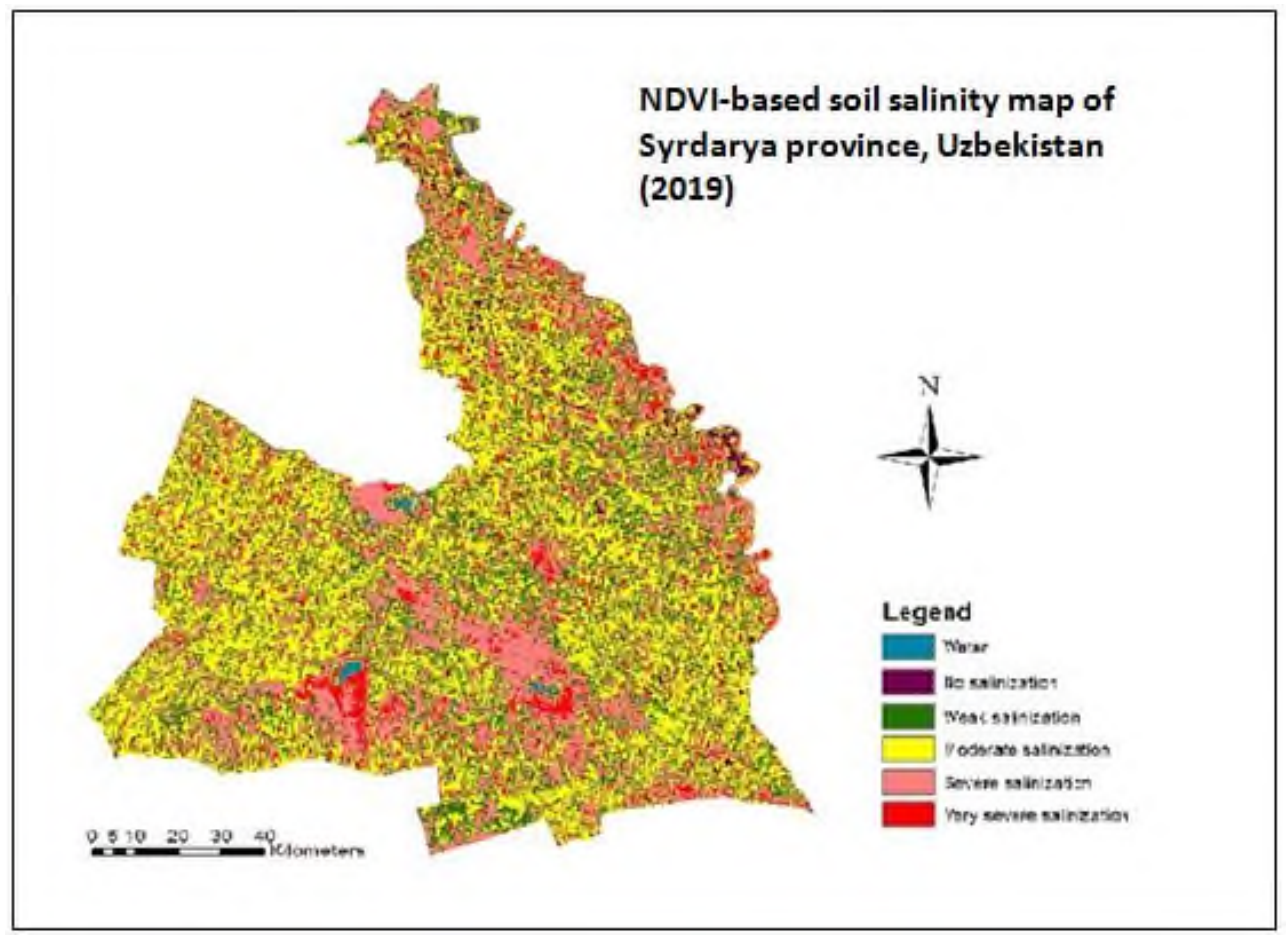

Fig. 3. Illustration of soil salinity levels of the study area.

The salinity map above exhibits itself that moderate and severe salt affected soils were predominant in Syrdarya province, except from the northern part. However, it can be met very high concentration of salt contents on topsoil in the central and western-central territory of the province in 2019.

The statistical analysis of area changes for diverse soil salinity level indicated in Fig. 4 below:

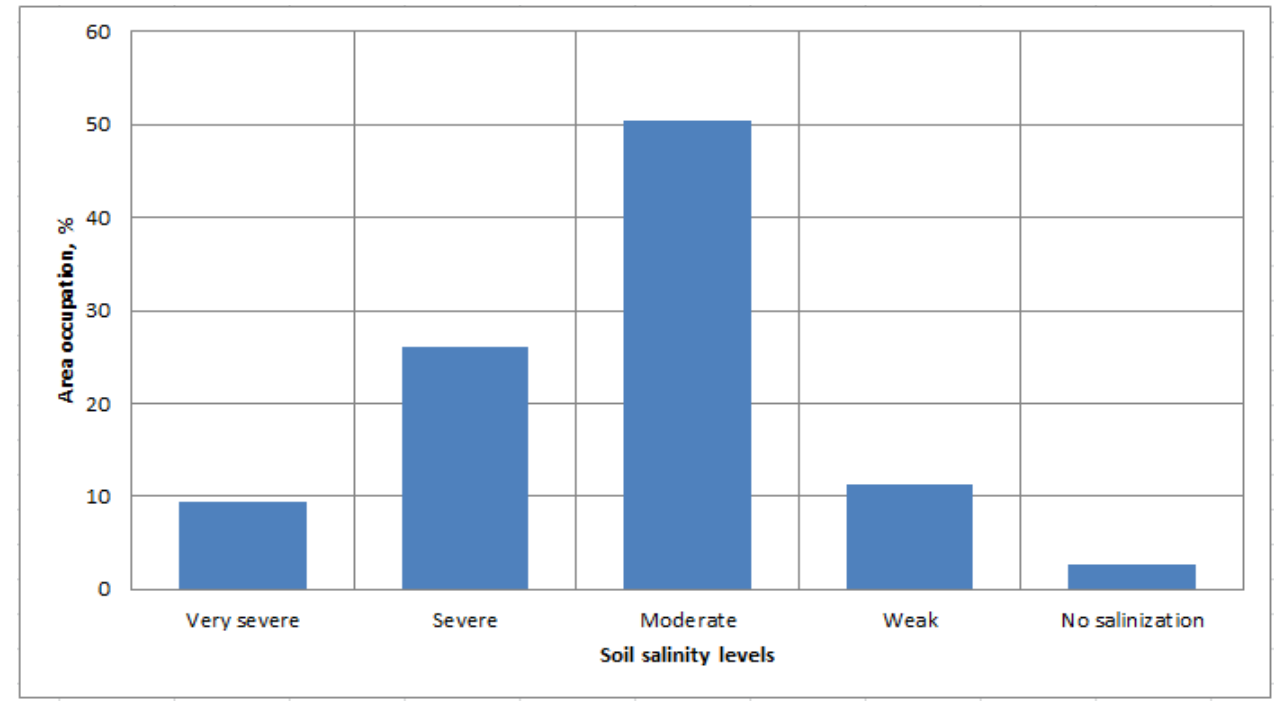

Fig. 4. Changes of area (measured by percentages of total arable land area) for salinity level of soil in Syrdarya province. 
According to Fig. 2 illustrating soil quality index values of different districts of Syrdarya province, every arable land validity point of different locations were measured by State Commite of the Republic of Uzbekistan of Land Resources, Geodesy, Cartography and State Cadastre (SCRULRGCSC) was compared to our research conducted on satellite sensor and it can be said that the study have done correctly.

Platonov et al [12] gave recommendations to decrease cost of mapping of soil salinization. To use the multi-temporal satellite images for creation of soil salinity map and to collect the soil samples from limited amount of points inside the fields with different gradation of soil salinity from soil salinity map were indicated and it was mentioned that use of this approach will increase the accuracy of soil salinity map with minimum expenditures on soil sampling.

Akramkhanov et al [1] mentioned on the research that significant correlations between quantifiable terrain attributes and soil salinity exist. Such a relationship was successfully used to estimate soil salinity at farm scale solely based on quantified environmental variables. Therefore, the environmental variables must be available for the study area in high resolution or easily measurable.

\section{Conclusion}

Soil sampling is a costly, time and labor consuming activity with the average norm for soil sampling being 15-20 points per day by one soil specialist and two workers. So, the satellite remotely sensed images are freely available now from Internet, and owing to our study, through satellite sensors, level of land degradation as an example of soil salinization can be measured $80 \%$ correctly. Consequently, using GIS and RS for soil salinity mapping is extremely cost-effective with a higher degree of spatial accuracy. Our results displayed almost all of arable land territories are mostly in danger by different types of salinity level. As far as there is not taken proper and prompt measures in this field, it will negatively reflects to our economy and agriculture.

\section{References}

1. A. Akramkhanov, P. L. Vlek, Environmental Monitoring and Assessment, 184(4), 2475-2485 (2012)

2. Z. Mamatkulov, E. Safarov, R. Oymatov, I. Abdurahmanov, M. Rajapbaev, E3S Web Conf., 227, 03001 (2021)

3. A. Allbed, L. Kumar, Advances in remote sensing, 2(04), 373 (2013)

4. B. Alikhanov, S. Alikhanova, R. Oymatov, Z. Fayzullaev, A. Pulatov, IOP Conf. Ser.: Mater. Sci. Eng., 883(1), 012088 (2020)

5. S. Eltazarov. Soil salinity assessment in Syrdarya Province, Uzbekistan, Wageningen University 901018-223-040 (2016)

6. Y. Peng, F. Li, N. Xu, R. Kulmatov, K. Gao, G. Wang, Y. Zhang, Y. Qiao, Y. Li, H. Yang, S. Hao, Q. Li, S. Khasanov, Chinese Journal of Eco-Agriculture, 29(2), 312-324 (2021)

7. B. Matyakubov, Z. Mamatkulov, R. Oymatov, U. Komilov, G. Eshchanova, InterCarto. InterGIS, 26, 229-239 (2020)

8. First President's Decree of Uzbekistan No-1958, April 13, 2013

9. S. K. Isaev, R. U. Rakhmonov, S. S. Tadjiev, G. I. Goziev, S. Z. Khasanov, IOP Conf. Ser.: Earth Environ. Sci., 614(1), 012147 (2020) 
10. T. K. Ghabour, L. Daels, Egyptian Journal of Soil Science, 33(4), 355-370 (1993)

11. Hydrologic Meliorative Expedition of Syrdarya Province. Annual report, 257 (2019)

12. A. Platonov, A. Noble, R. Kuziev, Developments in Soil Salinity Assessment and Reclamation, 87-98 (2013)

13. State Commite of the Republic of Uzbekistan of Land Resources, Geodesy, Cartography and State Cadastre. National report, 186 (2019)

14. State Scientific Research Institute of Soil Science and Agro chemistry. Annual report 79 (2019)

15. United States Geological Survey. Information of satellite images (2020). 